\title{
EFFECT OF DRYING PROCESS ON MARUPÁ WOOD COLOR
}

\author{
Joaquim Carlos Gonçalez ${ }^{1, \star}$, Márcia Helena Bezerra Marques ${ }^{2}$, Maria Cristina Sousa Karas ${ }^{3}$, \\ Gerard Janin ${ }^{4}$, Patricia Gomes Ribeiro ${ }^{5}$
}

\begin{abstract}
This research was developed after consultations with tropical timber exporters, who were facing problems with the colors of the species under study. This work aimed at characterizing Simarouba amara tropical wood color and verifying possible differences between the colorimetric parameters determined for the tangential and the radial directions of the wood, kiln-dried and air-dried. S. amara wood presents a grayish-white color. This color is mainly characterized by the $b^{*}$ coordinate (yellow pigment). Depending on the drying method used, the wood may present different colors for both tangential and radial directions. In both drying methods conducted, the wood presented lighter color in the tangential direction. Kiln-drying appeared to reduce $S$. amara wood lightness.
\end{abstract}

Keywords: Simarouba amara, color, directions, drying methods.

\section{INTRODUCTION}

Quality criteria for wood destined to specific uses must be defined. Wood quality regards its capacity of fulfilling the necessary requirements for product manufacturing. For instance, with respect to wood utilization in the furniture industry, color and aesthetic properties are decisive, while in construction strength is the most important criterion. Furthermore, the technological characteristics of the tree must be taken into account, which supports the best utilization of its wood for commercial purposes. Therefore, wood suitable for construction must be characterized mainly by considering its mechanical resistance.

In the same way, wood valorization as sheets or sawn wood, when used by the furniture segment or for other indoor purposes, depends on its aspect, aesthetics, design and, especially, color (Gonçalez 2003).

Wood color is an organoleptic property. This parameter is frequently used in developed countries, especially by Europeans, in order to evaluate the quality of sawn or laminated wood. This characteristic is oftenly associated to the figure and the design of each wood.

The chemical substances present in the trunk can be pointed out within the factors responsible for this property. Wood color intensity varies from light beige to dark brown, almost black. In addition, wood can present yellowish, reddish and orangish colors. Color tends to change over time, darkening especially due to the oxidation of some of its elements caused by, mainly, ultraviolet irradiation from sunlight (George et al. 2005).

Colorimetry is a scientific, objective and quantitative measure of an object color. It enables to transform colored sensations perceived and observed in the human eye into three numbers, through a spectrophotometer (Gonçalez 2003).

\footnotetext{
$\mathrm{PhD}$, Professor at the University of Brasília (UnB) - Department of Forest Engineering - 70919-900 Brasília DF.

2 PhD, Researcher at the Forest Products Laboratory - SFB -.70919-900 Brasília DF, márcia@lpf.ibama.gov.br

${ }^{3}$ Master's in Forest Sciences - 70919-900 Brasília DF. maria_cristn@hotmail.com

${ }^{4} \mathrm{PhD}$ in Colorimetry. Researcher at INRA/France. Collaborator at the University of Brasilia. gejanin@free.fr

5 PhD, Student in Forest Sciences - UnB - 70919-900 Brasília DF. patyballs@ pop.com.br

^ Corresponding author: goncalez@unb.br

Received: 23.05. 2013 Accepted: 30.102013
} 
All colors are consequence of light action, mainly influenced by its intensity and energy distribution in each wave length in the blue, yellow - green and red domains, as well as by its reflection on object surfaces.

The first and most important value is clarity $\left(\mathrm{L}^{*}\right)$, followed by the coordinates $\mathrm{a}^{*}$ and $\mathrm{b}^{*}$. The asterisk indicates that it belongs to the 1976 CIELAB System, recommended by the 1931 Commission Internationale de l'Eclairage. According to CIELAB, all colors belong to the system, which presents three coordinates: $L^{*}, a^{*}, b^{*}$. $L^{*}$ regards color lightness within a numeric scale, from 0 to 100 , similar to a grey-level scale in which zero is black and 100 is white. The chromatic coordinate a* regards the color point position on the green-red axis, presenting value between 0 and 60 ; on the other hand, the chromatic coordinate $b *$ is related to the position of the same color point on a blue axis, perpendicularly $\left(90^{\circ}\right)$ to the green-red axis within the color plan, also showing values between 0 and 60 (Gonçalez 1993).

Based on the CIELAB System, a method known as CIELCh System was developed to express the color. It is based on the fact that each color is defined by lightness $\left(\mathrm{L}^{*}\right)$, saturation $(\mathrm{C})$ and hue angle (h*) (Janin et al. 2001).

Wood color is an important value of consideration in the wood industry and this is been influenced by the drying process. Several businessmen affirm that drying tends to cause change of wood original color, while others believe that it varies according to the species. There are also ones who believe that drying does not affect wood color. The drying process aims at the reduction of wood humidity, with minimum of defects and in the shortest possible time. It is the intermediary stage between the primary wood processing (log sawing) and the secondary (processing). It is a simple and easy process, but requires some special care. It is a very important stage in the processes of wood transformation in products. The literature is vast when it comes to studying the behavior of wood by heat treatments, that is, the submission of timber to temperatures above $150^{\circ} \mathrm{C}$ to improve its properties (Borges and Quirino 2004, Sundqvist 2004, Esteves and Pereira 2009, Pincelli et al. 2012). However, researches about timber drying process and possible effects on its properties are scarcer (particularly concerning color). Depending on the drying process conducted, natural or artificial, and the type of wood dried, the influence of the procedure on color change may be more or less significant. In some cases, timber utilization might even be compromised, especially if product aesthetics is modified by the change in color.

Marupá (Simarouba amara) wood, both massive and as slides, is gaining ground in the furniture industry. In Brazil, this raw material comes mostly from the Amazon Forest, but it also comes from plantation forest.

The objective of this work was to verify the drying method (kiln and open air) effect on the colorimetric parameters determined in the tangential and radial directions of $S$. amara tropical wood.

\section{MATERIAL AND METHODS}

This research was carried out in the Forest Products Laboratory - LPF/IBAMA, located in Brasília (DF).

The species studied was Simarouba amara Aubl. The wood was commercially acquired, whereas the wood boards (total of 12) were taken from six 0,75-m width, 0.50-m thick and 2.70-m length planks from six trees removed from a natural forest located near the city of Ji-Paraná (RO). The 12 samples without core, presenting $140-\mathrm{mm}$ width, $25-\mathrm{mm}$ thick and 500-mm length, were removed tangentially to the growth rings and put in sinks containing water, where they remained submerged until the drying treatments were applied. 
S. amara wood was subjected to conventional kiln drying and air drying. Six samples were used in each treatment.

The samples subjected to conventional kiln drying were removed from the sinks filled with water and vertically stacked to eliminate the excess of water. Asphalt aqueous solution was used to waterproof the top part of the samples (the cut ends of each plank) in order to avoid an abrupt humidity loss during the drying process.

The boards were dried in a Hildebrand kiln for testing, whose model was TKA-HD II, equipped with Gann automatic control.

The procedure for drying the samples of $S$. amara wood followed the program recommended by Marques et al. (1997). Air velocity was kept between 2,5 and 2,8 m/s and the load was submitted to a 3 -hour heating period. The drying process began right after this period and was carried out until a $10 \%$ final humidity in dry base was reached. Afterwards, the timber was packed for a six-hour period for standardizing the humidity in each board and to release the tensions eventually developed during the drying process.

Air drying was carried out in a covered and ventilated shed located in the LPF facilities, according to the methodology described by Martins (1988).

The tops of the boards were sealed and then stacked on concrete buttresses, whereas the first layer of boards was $30 \mathrm{~cm}$ above ground level. Thick spacers (15-mm thick) were used in order to enable air circulation between the layers. The pile was transversely positioned to wind's main direction. The drying process was interrupted when mean humidity reached the best value possible according to climatic conditions $(10 \pm 1 \%)$. A thermohygrograph was used to register room temperature and relative humidity of the air.

After kiln and air drying processes, the samples were placed in a climatized environment (temperature of $20 \pm 1{ }^{\circ} \mathrm{C}$ and relative humidity of the air $65 \pm 2 \%$ ) for equalizing humidity levels. Afterwards, in order to clean the surface, one 150-grit sandpaper was used for gentle sanding of one radial and one tangential face of the samples. Both tangential and radial surfaces of all samples from both groups were scanned for determining colorimetric readings. Twenty-five color readings were performed in each direction (tangential and radial) of each sample, accounting for 150 measures for the six samples.

It was used a Datacolor International Microflash spectrophotometer, model 200. The colorimetric readings measured were: lightness $\left(\mathrm{L}^{*}\right)$, the red-green axis coordinate $\left(\mathrm{a}^{*}\right)$ and the blue-yellow axis coordinate $\left(b^{*}\right)$. The saturation $(C)$ and hue angle $\left(h^{*}\right)$ parameters were obtained from $L^{*}, a^{*}$ and $b^{*}$. In order to calculate $\mathrm{a}^{*}$ and $\mathrm{b}^{*}$ coordinates as well as $\mathrm{C}$ and $\mathrm{h}^{*}$ parameters, the same proceeding carried out by Gonçalez (1993) was employed, according to the 1976 CIELAB System. Within Microflash options for standard illuminants, the A10 illuminant - incandescent light - and $10^{\circ}$ of observation angle was selected.

The values obtained for the colorimetric readings were statistically analyzed by analysis of variance with factorial ( $2 \times 2)$ arrangement, in which it was tested the effects of the drying method, direction in the wood and their interaction.

The significant values by $\mathrm{F}$ test were analyzed by Tukey's test at 5\% probability. 


\section{RESULTS AND DISCUSSION}

The average values of the colorimetric readings found in Simarouba amara wood characterization are presented on table 1 . The results were compared to other species traditionally used in the wood industry for an easier visualization and understanding.

Table 1. Average values of the colorimetric readings $\left(\mathrm{L}^{*}, \mathrm{a}^{*}, \mathrm{~b}^{*}, \mathrm{C}, \mathrm{h}^{*}\right)$ for $S$. amara wood compared to four traditionally used species.

\begin{tabular}{l|l|l|l|l|l}
\hline \multicolumn{1}{c|}{ Species } & \multicolumn{1}{c|}{$\mathbf{L}^{*}$} & \multicolumn{1}{c|}{$\mathbf{a}^{*}$} & \multicolumn{1}{c|}{$\mathbf{b}^{*}$} & $\mathbf{C}$ & \multicolumn{1}{c}{$\mathbf{h}^{*}$} \\
\hline Marupá (1) & 80,24 & 3,64 & 21,26 & 21,57 & 80,32 \\
\hline Mogno (2) & 52,10 & 14,60 & 28,70 & 32,10 & 63,10 \\
\hline Ipê (2) & 39,00 & 10,00 & 16,00 & 18,90 & 58,00 \\
\hline Eucalyptus grandis(2) & 63,62 & 11,90 & 17,43 & 21,12 & 55,74 \\
\hline Pau-marfim (2) & 84,10 & 3,30 & 21,80 & 22,10 & 81,40 \\
\hline \multicolumn{2}{l|}{ (I) Average of 600 readings }
\end{tabular}

It is shown in table 1 that $S$. amara wood lightness $\left(\mathrm{L}^{*}\right)$ is 80,24 . According to Camargos (1999), when $\mathrm{a}^{*}$ and $\mathrm{b}^{*}$ parameters and $\mathrm{h}^{*}$ hue angle are aggregated, this wood presents a grayish-white color. The yellow pigment, given by coordinate $b^{*}$, is determiner in this species color characterization. Coordinate $\mathrm{a}^{*}$, which represents the red pigment, contributes to pigmentation mixture and is the main contributor to the origin of the grayish color. The hue angle ( $\left.\mathrm{h}^{*}\right)$ shows value of 80,32 complementing the color characterization, as it situates this species wood closer to the yellow axis in the 1976 CIELAB System (Gonçalez et al. 2001), indicating the $b^{*}$ coordinate influence.

In fact, when this species color is compared to others popular in the wood market, some similarity to the "pau-marfim" wood can be verified. "Pau-marfim" colorimetric readings are similar to S. amara (Table 1) ones. Indeed, throughout Brazil, S. amara is commercialized as "pau-marfim" or similar names such as "marfim-do-norte", "pau-marfim-paraguai", among others. An analysis of the species in table 1 indicates this methodology efficiency, since the values of the colorimetric readings are specific for each wood.

The F-values for the colorimetric readings ( $\mathrm{L}^{*}, \mathrm{a}^{*}, \mathrm{~b}^{*}, \mathrm{C}$ and $\mathrm{h}^{*}$ ) obtained in the analysis of variance performed, considering treatments (kiln-drying and air-drying), directions (tangential and radial) and interactions, are presented in table 2. According to the results, it is observed that the drying method effect depends on the sawing direction of the wood for the colorimetric readings, except for the lightness variable $\left(\mathrm{L}^{*}\right)$.

Table 2. Summary of the analysis of variance of $S$. amara wood colorimetric readings $\left(L^{*}, a^{*}, b^{*}\right.$, $\mathrm{C}, \mathrm{h}^{*}$ ) for drying methods and wood fiber directions.

\begin{tabular}{l|c|c|c|c|c|c}
\hline \multirow{2}{*}{ Source of variation } & Degrees of & \multicolumn{5}{|c}{ F-values } \\
\cline { 3 - 7 } & liberty & $\mathbf{L}^{*}$ & $\mathbf{a}^{*}$ & $\mathbf{b}^{*}$ & $\mathbf{C}$ & $\mathbf{h}^{*}$ \\
\hline Treatment & 1 & $11,95^{\mathrm{a}}$ & $3,87^{\mathrm{a}}$ & $24,07^{\mathrm{a}}$ & $22,96^{\mathrm{a}}$ & $<1^{\mathrm{ns}}$ \\
\hline Direction & 1 & $12,13^{\mathrm{a}}$ & $1,10^{\mathrm{ns}}$ & $12,61^{\mathrm{a}}$ & $12,08^{\mathrm{a}}$ & $1,99^{\mathrm{ns}}$ \\
\hline Treatment x Direction & 1 & $<1^{\mathrm{ns}}$ & $11,98^{\mathrm{a}}$ & $8,96^{\mathrm{a}}$ & $9,33^{\mathrm{a}}$ & $8,26^{\mathrm{a}}$ \\
\hline Residual & 596 & & & & & \\
\hline Coefficient of variation & & 5,97 & 15,84 & 8,01 & 8,12 & 1,35 \\
\hline
\end{tabular}

${ }^{\mathrm{a}}$ Significant values and ${ }^{\mathrm{ns}}$ Non-significant values at $5 \%$ probability. 
The colorimetric readings of $S$. amara wood are significantly influenced depending on the drying method applied to it, except for the $\mathrm{h}^{*}$ parameter. Both lightness $\left(\mathrm{L}^{*}\right)$ and $\mathrm{a}^{*}$ and $\mathrm{b}^{*}$ coordinates, responsible for the red and yellow pigments of the wood, respectively, may present changes depending on the type of drying method used. Thus, the final color of the wood species will be influenced by such method of wood drying to which it has been subjected.

The analysis of the sawing direction influence indicates once more that the colorimetric readings present significant differences; in other words, the wood presents color differences depending on the grain orientation (tangential or radial face), except for the variables $\mathrm{a}^{*}$ and $\mathrm{h}^{*}$.

The low coefficient of variation $(\mathrm{CV})$ values obtained indicate that the research presented a good experimental control.

After realizing that S. amara wood color may change, depending on the drying method used and, or, on the sawing method, Tukey's test was carried out to verify the drying method effect on each direction analyzed (Table 3 ).

Table 3. Averages of the colorimetric readings $\left(L^{*}, a^{*}, b^{*}, C, h^{*}\right)$ for air-dried and kiln-dried S. amara wood for tangential and radial directions.

\begin{tabular}{c|c|c|c|c|c|c}
\hline \multirow{2}{*}{ Treatment } & Direction & \multicolumn{5}{|c}{ Average values } \\
\cline { 3 - 7 } & $(\mathbf{b})$ & $\mathbf{L}^{*}$ & $\mathbf{a}^{*}$ & $\mathbf{b}^{*}$ & $\mathbf{C}$ & $\mathbf{h}^{*}$ \\
\hline \multirow{2}{*}{ Kiln-drying } & Radial & $78.74 \mathrm{~A}$ & $3.64 \mathrm{~A}$ & $20.87 \mathrm{~A}$ & $21.26 \mathrm{~A}$ & $80.13 \mathrm{~A}$ \\
\cline { 2 - 7 } & Tangential & $80.40 \mathrm{~B}$ & $3.53 \mathrm{~B}$ & $20.95 \mathrm{~A}$ & $21.20 \mathrm{~A}$ & $80.50 \mathrm{~B}$ \\
\hline \multirow{2}{*}{ Air-drying } & Radial & $80.38 \mathrm{~A}$ & $3.79 \mathrm{~A}$ & $21.14 \mathrm{~A}$ & $21.45 \mathrm{~A}$ & $80.38 \mathrm{~A}$ \\
\cline { 2 - 7 } & Tangential & $81.45 \mathrm{~B}$ & $3.58 \mathrm{~B}$ & $22.05 \mathrm{~B}$ & $22.38 \mathrm{~B}$ & $80.25 \mathrm{~A}$ \\
\hline
\end{tabular}

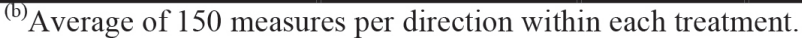

Average values followed by the same letter, within each column and for each treatment, did not differ statistically by Tukey's test at $5 \%$ probability.
}

According to table 3, lightness $\left(\mathrm{L}^{*}\right)$, not only for kiln-dried but also for air-dried wood, is higher in the tangential direction compared to the radial direction. In both situations, the yellow pigment $\left(\mathrm{b}^{*}\right)$ characterized $S$. amara wood color. Coordinate a* (red pigment) helps to explain the lower lightness of the radial face for both treatments. The colorimetric reading $\mathrm{h} *$ complements this explanation for kiln drying, presenting the hue angle in the tangential direction closer to the yellow axis in the 1976 CIELAB System, culminating with lighter wood color in this direction. In the air drying, the $b^{*}$ coordinate contributes to explaining the highest lightness of the tangential direction. In this case, saturation $(\mathrm{C})$ is also higher, contributing to characterize the lighter color of the wood.

\section{CONCLUSIONS}

S. amara wood color and sawing direction (radial or tangential) are important characteristics in this species utilization, enabling certain value aggregation in the wood industry, especially for indoor utilization.

$S$. amara wood color is characterized by the colorimetric readings $\mathrm{L}^{*}=80.24 ; \mathrm{a}^{*}=3.64 ; \mathrm{b}^{*}=21.26$; $\mathrm{C}=21.57$; and $\mathrm{h}^{*}=80.32$. This wood presents grayish-white color, which is similar to the "pau-marfim" (Balfourodendron riedelianum) wood color. 
The drying method effect on the colorimetric readings of $S$. amara wood (kiln or air drying) depends on the sawing direction (radial or tangential).

Lightness $\left(\mathrm{L}^{*}\right)$ of both kiln-dried and air-dried wood is higher in the tangential than in the radial direction. In both cases, the yellow pigment $\left(\mathrm{b}^{*}\right)$ characterized S. amara wood color. Therefore, if industry requires lighter wood, log sawing must be tangential to growth rings.

Overall, air-dried S. amara wood presents lighter color than that kiln dried. Possibly, the higher temperatures used in the kiln-drying process contribute for the reduction in wood lightness.

\section{REFERENCES}

Borges, L.M.; Quirino, W.F. 2004. Higroscopicidade da madeira de Pinus caribaea var. hondurensis tratado termicamente. Revista Biomassa \& Energia 1(2): 173-182.

Camargos, J.A.A. 1999. Colorimetria quantitativa aplicada na elaboração de uma tabela de cores para madeiras tropicais. Dissertação (Mestrado em Ciências Florestais), Universidade de Brasília, Brasília, Brasil.

Esteves, B.M.; Pereira, H.M. 2009. Wood modification by heat treatment: A Review. BioResources 4 (1): 370-404.

George, B.; Suttie, E.; Merlin, A.; Deglise, X. 2005. Photodegradation and photostabilisation of wood - the state of the art. Polymer Degradation and Stability (88): 268-274.

Gonçalez, J.C. 1993. Caracterisation technologique de quatre espéces peu connues da la forêt Amazonienne: anatomie, chimie, couleur, propriétés physiques et mécaniques. These (Docteur en Sciences du bois), ENGREF, Nancy, France.

Gonçalez, J.C. 2003. Colorimetria aplicada à madeira de eucalipto. In: seminário de produtos sólidos de madeira de eucalipto. Anais MADETEC. Belo Horizonte. Minas Gerais.

Gonçalez, J.C.; Janin, G.; Santana, A.C.; Costa, A.F.; Valle, A.T. 2001. Colorimetria quantitativa: uma técnica objetiva de determinar a cor da madeira. Brasil Florestal 20 (72): 47-58.

Janin, G.; Goncalez, J.; Ananias, R.; Charrier, B.; Fernandes, G.; Dilem, A. 2001. Aesthetics appreciation of wood colour and patterns by colorimetry. Part 1. Colorimetry theory for the CIELab Sistem. Maderas. Ciencia y tecnología 3(1-2): 3-13

Marques, M. H. B.; Melo, J.E. 1997. Madeiras da Amazônia: características e utilização, Amazônia Oriental. Brasília: IBAMA 3, 141p.

Martins, V. A. 1988. Secagem de madeira serrada. Brasília: $I B D F, 56 \mathrm{p}$.

Pincelli, A S. M; Moura, L.F.; Brito, J. O. 2012. Effect of thermal rectification on colors of Eucalyptus saligna and Pinus caribaea woods. Maderas. Ciencia y tecnología 14(2): 239-248.

Sundqvist, B. 2004. Color Changes and Acid Formation in Wood During Heating. 2004. Thesis (Doctoral) - Division of Wood Material Science, Lulea University of Technology, Skellefta, Sweden. 